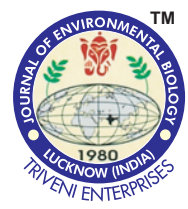

\title{
Effect of temperature on egg development time and productivity of Acartia steueri and population variations of family Acartiidae in Dadaepo Beach, Busan, Korea
}

\section{Authors Info \\ Y.J. Jo', W. Park ${ }^{1 *}$, B. W. Lee ${ }^{1}$, C. G. Kang ${ }^{2}$ and Y.E. Kim ${ }^{3}$ \\ ${ }^{1}$ Department of Marine Biology, Pukyong National University, Busan, 48513, Korea \\ ${ }^{2}$ School of Earth Sciences and Environmental Engineering, GIST, Gwangju, 61005, Korea \\ ${ }^{3}$ Department of Marine Biotechnology, Soonchunhyang University, Asan, 31538, Korea}

*Corresponding Author Email : wpark@pknu.ac.kr

Edited by

Professor Chae Woo Ma

Reviewed by

Professor Jae Won Kim

Professor Chung II Lee

\section{Abstract}

Aim: This research aimed to study the effect of temperature on egg production rate, egg development time, hatching success rate and egg size of Acartia steueriand seasonal variation of species composition of family Acartiidae.

Methodology: Population variations of Acartiidae were investigated based on weekly collected samples from Dadaepo beach, Busan, Korea. Live copepods were reared in laboratory at five temperature regimes $\left(10,14,18,22\right.$ and $\left.26^{\circ} \mathrm{C}\right)$ to estimate temperature effects on the egg development time and productivity of $A$. steueri.

Results: Total five acartiid species were found in the study area: Acartia omorii, A. steueri, A. pacifica, A. erythraea, and $A$. sinjiensis. A. steueri and $A$. omorii were dominated in colder months from January to April, while $A$. pacifica, $A$. erythraea and $A$. sinjiensis were abundant during warmer months from August to December. Egg production rates were significantly correlated with water temperature. The embryonic development time of $A$. steueri was longest at $10{ }^{\circ} \mathrm{C}$ and shortest at $22^{\circ} \mathrm{C}$. The egg size decreased with increase in water temperature.

Interpretation: This study indicated that temperature influenced embryonic development rate, generation time and population variations of acartiid copepods.

Key words: Acartia steueri, Dadaepo beach, Egg production rate, Population variation

To study temperature effects on the egg production rate and development time, and hatching success of $A$. steueri and to investigate the seasonal variation of species composition of family Acartiidae

\begin{tabular}{|c|c|}
\hline Laboratory Experiment & Field Experiment \\
\hline $\begin{array}{l}\text { - Five temperature regimes }\left(10,14,18,22 \text { and } 26^{\circ} \mathrm{C}\right) \\
\text { - Egg production rate; - Development time } \\
\text { - Hatching success rate; - Egg size }\end{array}$ & $\begin{array}{l}\text { - Weekly collected samples } \\
\text { - Population variations }\end{array}$ \\
\hline \multicolumn{2}{|c|}{1} \\
\hline Laboratory Experiment & Field Experiment \\
\hline $\begin{array}{l}\text { - Egg production rates correlated with temperature. } \\
\text { - Egg size decreased when temperature increased } \\
\text { - Egg development time and hatching success of } A \text {. } \\
\text { steueri was longest and lowest at lower temperature. }\end{array}$ & $\begin{array}{l}\text { - Total five Acartiid species : Acartia omorii, A. steueri, } \\
\text { A. pacifica, A. erythraea, A. sinjinensis } \\
\text { - Colder months (From January to April) } \\
\text { : A. steueri, A. omorii dominented } \\
\text { - Warmer months (From August to December) } \\
\text { : A. pacifica, A. erythraea, A. sinjinesis }\end{array}$ \\
\hline
\end{tabular}

This study indicated that temperature influenced embryonic development rate, generation time and population variation of acartiid copepods.

How to cite : Jo, Y.J., W. Park, B.W. Lee, C.G. Kang and Y.E. Kim: Effect of temperature on egg development time and productivity of Acartia steueri and population variations of family Acartiidae in Dadaepo Beach, Busan, Korea. J. Environ. Biol., 40, 962-968 (2019). DOI : http://doi.org/10.22438/jeb/40/5(SI)/SI-19 


\section{Introduction}

Copepod metabolism can be controlled by exterior environmental factors such as temperature, salinity and food concentrations (Landry, 1975; Miller et al., 1977). In particular, temperature is an important factor for the population variations (Uye, 1982; Liang and Uye, 1996), life histories such as reproductive rate and growth rate (Lee et al., 2003), egg production rate and hatching success (Ara, 2001; Begum et al., 2012). Increasing water temperature accelerates egg production rate and hatching success, and shortens egg development time (Landry, 1975). Water temperature changes driven by climate changes can adjust strategically their egg production to maintain populations (Uye, 1982; Hays et al., 2005).

Copepods of family Acartiidae are common inhabitants of coastal water in all oceans of the world (Uye, 1980, 1981; Kang and Kang, 1998; Yoo et al., 1991; Mauchline, 1998). The abundance of members belonging to family varies with seasons. Acartia longiremis is dominant in colder season while $A$. steueri is dominant in the warmer season at Okkirai Bay in Japan (Yamada et al., 2012). A. longiremis, A. omorii and A. hudsonica appears from early spring to summer. The abundance of $A$. steueri increases during summer, decreases until January, and then disappears for two or three months from April at Okkirai Bay in Japan(Yamada et al., 2012).

Dadaepo beach is located towards Tsushima Warm Current and flows from Southern Sea of Korea. Tsushima Warm Current may transport multi species of family Acartiidae and result in seasonal community changes of acartiid species in the area. Dadapo beach displays a gentle slope within $100 \mathrm{~m}$ with high nutrients, due to tidal mixing (Na et al., 1990). Primary production in Dadaepo beach is high, resulting in high abundance of copepods (Na et al., 1990).

This research was carried out to study temperature effects on egg production rate and development time, and hatching success of $A$. steueri, and also to investigate the relationship between water temperature and species composition of family Acartiidae in the study area.

\section{Materials and Methods}

Sampling and maintenance of live specimens : Zooplankton was horizontally sampled using a conical zooplankton net $(45 \mathrm{~cm}$ in mouth diameter and $330 \mu \mathrm{m}$ in mesh size) at Dadapo beach, Busan, Korea during two weeks in March 2016. Live copepods were transported within hours to laboratory. Adult Acartia steueri were separated under a microscope and were placed in acrylic water tanks, maintained at similar temperature of the sampling site. Isochrysis galbana and Tetraselmis suecica obtained from Gyeongsangnam-Do Fisheries Research Institute were fed to adult $A$. steueri. During the experiment, sea water was changed two times per day.
Egg production rates and sizes : Live adult copepods were separated under microscope using a $0.5 \mathrm{ml}$ pipette. After two days of acclimation, live individuals were maintained in 2.5 I acryl container with full filled sea water of five temperature regimes $\left(10^{\circ} \mathrm{C}, 14^{\circ} \mathrm{C}, 18^{\circ} \mathrm{C}, 22^{\circ} \mathrm{C}\right.$ and $\left.26^{\circ} \mathrm{C}\right)$. After two days, each individual was put into the modified $60 \mathrm{ml}$ acryl cylinder containing filtered seawater and mixture of $I$. galbana and T. suecica for one week. Phytoplankton concentration at each cylinder was over the $10,000 \mathrm{cell} \mathrm{ml}^{-1}$. Ten replicates were made for same experimental condition. Photoperiod was $12 \mathrm{hr}$ light and $12 \mathrm{hr}$ dark.

The modified acrylic cylinder was designed to minimize the stress of copepods during the experiment. The upper part of acryl cylinder was $10 \mathrm{~cm}$ while lower part was $3 \mathrm{~cm}$ high. Considering the diameter of eggs (about $80 \mu \mathrm{m}$ ), the mesh size of upper part was $200 \mu \mathrm{m}$ and that of lower part was $30 \mu \mathrm{m}$.

Copepod eggs were collected, counted and fixed in $5 \%$ neutral formalin to determine the effects of water temperature on the egg size. The size of copepod eggs were measured under the microscope (Stereo discovery V12).

Hatching success rate and embryonic development time: Adult copepods were placed under the microscope using $0.5 \mathrm{ml}$ pipette. Ten copepods were cultured in a modified acryl container with sea water at five temperature regimes $\left(10^{\circ} \mathrm{C}, 14^{\circ} \mathrm{C}, 18^{\circ} \mathrm{C}\right.$, $22^{\circ} \mathrm{C}$ and $26^{\circ} \mathrm{C}$ ). After $4 \mathrm{hrs}, 1$ to 3 scattered eggs on the bottom of the container were placed in a 24 well plate container of $0.3 \mathrm{ml}$ of filtered sea water at five temperature regimes. Naupliar hatching was observed under the microscope every $4 \mathrm{hrs}$ hrs and hatched nauplii were removed from the well-plate. After $144 \mathrm{hrs}$ from the eggs to the last hatching time, unhatched eggs were determined as resting or failed hatching eggs.

The relationship between temperature and embryogenesis time was calculated by using Bělehrádek's equation (Corkett and McLaren, 1970).

$$
D_{E}=a(T-\sigma)^{b}
$$

Where, $D_{E}$ is the egg incubation time (day), $T$ is the water temperature $\left({ }^{\circ} \mathrm{C}\right)$, and $\mathrm{a}, \mathrm{b}$, and $\mathrm{a}$ are optimization constants. To obtain optimization constant, the equation was converted to log. a was arbitrarily substituted to obtain a having highest regression relationship, and $a$ and $b$ were obtained.

The equation converted to log is as follows:

$$
\log D_{E}=\log _{a}+\operatorname{blog}(T-a)
$$

Zooplankton sampling for population variations : Zooplankton was collected using a conical net based on weekly collected samples from Dadaepo beach, Busan, Korea from August 2015 to April 2016. The collected specimens were fixed in $70 \%$ alcohol, and then transported to laboratory for analysis. 
Water temperature and salinity were measured by thermometer and refraction salino meter.

Statistical analyse : One-way ANOVA was performed using SPSS program (Statistical Package for the Social Science, Version 12.0) to determine the difference by water temperature regimes between egg production rates, egg size and embryonic development time. The significance $(p<0.05)$ between the average was investigated by Tukey-test.

\section{Results and Discussion}

Environmental factors : The surface water temperature during the research period ranged from 9.8 to $25.4^{\circ} \mathrm{C}$. The surface temperature was lowest in January $2016\left(9.8^{\circ} \mathrm{C}\right)$ and the highest in August $2015\left(25^{\circ} \mathrm{C}\right)$. The salinity ranged from 30.7 to $34 \mathrm{psu}$ (Fig. 1).

The surface water temperature and salinity in the southern coast of Korea comprise a large seasonal pattern with temperature ranging from $8.4-26.7^{\circ} \mathrm{C}$ and salinity $15.0-34.3$ psu (Yun and Paik, 2001). The water temperature in the southern coast of Korea is influenced by warm current influx from the south, surface cooling and vertical mixing in winter and by rainfall and evaporation. Seasonal variation of sea water salinity and temperature in the study area may influence changes in egg development and production of zooplankton in the area.

Egg production rates: The egg production rates of $A$. steueri were estimated by averaging the counts of $A$. steuerieggs for one week in five temperature regimes (Table 1). The production range of $A$. steueri was $8.7-35.0$ per female, lowest at $10^{\circ} \mathrm{C}$, and highest at $22^{\circ} \mathrm{C}$. The egg production rates increased with elevating water temperature, but decreased sharply at $26^{\circ} \mathrm{C}$ $(p<0.05)$. The mortality rate of adult $A$. steueri was lowest at $26^{\circ} \mathrm{C}$ (Fig. 2).

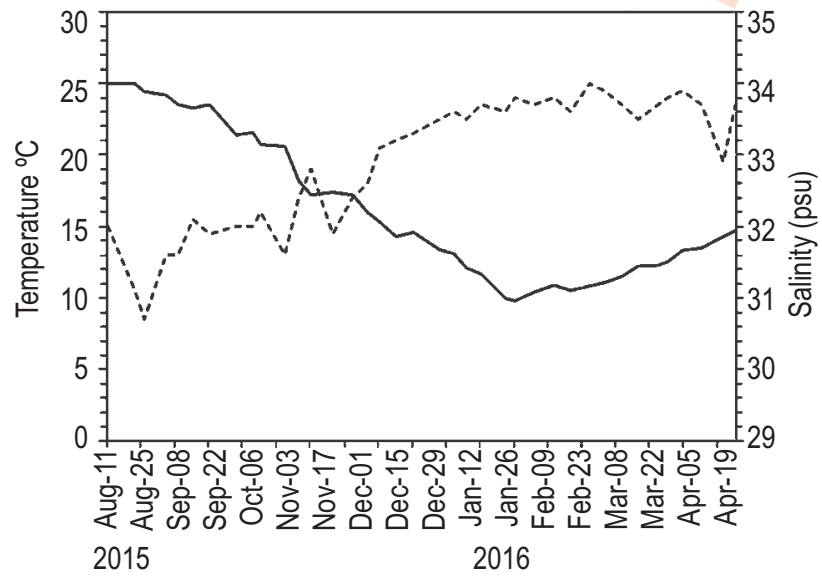

Fig. 1: Weekly variation of surface temperature (line) and salinity (dotted line) in the Dadaepo beach of Korea from August 2015 to April 2016.
The difference in egg production rate by temperature was analyzed through one way ANOVA test. There was a significant relationship between egg production rates and water temperatures (Table 2). There was no significant difference at $10^{\circ} \mathrm{C}$ and $14^{\circ} \mathrm{C}$, but there was a significant difference at other temperature regimes (Fig. 2).

Egg production rate is affected by water temperature, salinity and the quantity and quality of food (Koski and Kuosa, 1999; Castro-Longoria, 2003; Holste and Peck, 2006; Santhanam et al., 2013). In particular, the egg production rate of copepods increases with elevating temperatures (Ara, 2001). The highest productivity of Acartia tonsa was found at $23^{\circ} \mathrm{C}$ (Holste and Peck, 2006), while A. clausi and $A$. steueri in Onagawa Bay produced the highest number of eggs at $15^{\circ} \mathrm{C}$ and $20^{\circ} \mathrm{C}$ (Uye, 1981). The egg production rate of $A$. tonsa in Chesapeake Bay increased up to $27^{\circ} \mathrm{C}$, but was reduced at higher temperature (White and Roman, 1992). The egg production rate of $A$. bifilosa was also positively correlated with temperature. The number of eggs were highest at $18^{\circ} \mathrm{C}$ and the lowest at $24^{\circ} \mathrm{C}$ (Koski an Kuosa, 1999). Daily egg production rate of $A$. lilljeborgi ranged from 13.8 to 66.8 eggs per female per day. The highest egg production rate of $A$. clausi was observed in spring month at $8.6-$ $18.5^{\circ} \mathrm{C}$ whereas the lowest values were found in fall months with the ranges of $16.94-23^{\circ} \mathrm{C}$ (Üstün and Bat, 2014). The egg production rate of $A$. lilljeborgi increased as temperature increased from 19.5 to $25.2^{\circ} \mathrm{C}$, after then decreased between $28.4^{\circ} \mathrm{C}$ and $29.1^{\circ} \mathrm{C}$ in Cananéia Lagoon estuarine (Ara, 2001). The egg production rate tended to decrease sharply above the optimum water temperature (Uye, 1981).

In this study, egg production rates also increased with increasing temperature up to $22^{\circ} \mathrm{C}$. When water temperature was over $22^{\circ} \mathrm{C}$, the egg production rate decreased rapidly. The optimal water temperature in each copepod sampling site varied from $18^{\circ} \mathrm{C}$ to $27^{\circ} \mathrm{C}$. This research indicates that copepods may acclimatize to the water temperature of their respective regions, which may affect the egg production rate, further leading to variation in the populations.

Egg size : The average egg size of $A$. steueri in five temperature regimes ranged from 72.51 to $82.74 \mu \mathrm{m}$. The egg size decreased when the water temperature increased, the mean egg sizes were 82.74, 77.29, 75.92, 73.65, and $72.5 \mu \mathrm{m}$, respectively (Fig. 3).

One way ANOVA was used to test the variations of egg sizes by water temperature. There was a significant relationship between egg sizes and water temperatures $(p<0.05)$.

The egg size is affected by temperature and quantity of food (Zamora-Terol and Saiz, 2013; Woodward and White, 1981). The egg size increases with increasing food concentration due to change in the amount of protein, carbohydrate and lipid concentration (Guisande and Harris, 1995). In particular, the egg 
Table 1: Mean egg production of Acartia steueriat five different temperatures

\begin{tabular}{lllll}
\hline $\begin{array}{l}\text { Temperature } \\
\left({ }^{\circ} \mathrm{C}\right)\end{array}$ & $\begin{array}{l}\text { No. of total } \\
\text { females }\end{array}$ & $\begin{array}{l}\text { No. of experimental } \\
\text { females }\end{array}$ & $\begin{array}{l}\text { Average egg production } \\
\text { (eggs/female/day) }\end{array}$ & S.D. \\
\hline 10 & 10 & 7 & 8.7 & 0.75 \\
14 & 10 & 8 & 13.4 & 1.36 \\
18 & 10 & 7 & 28.4 & 1.75 \\
22 & 10 & 7 & 35.0 & 2.89 \\
26 & 10 & 9 & 20.7 & 2.28 \\
\hline
\end{tabular}

Table 2: Analysis of variance (ANOVA test) of egg production of Acartia steueriat five different temperatures

\begin{tabular}{lllll}
\hline Source of variation & d.f & Sum of squares & Mean squares & F \\
\hline Temperature & 4 & 3267.7 & 816.9 & 23.20 \\
\hline$P<0.05$
\end{tabular}

$P<0.05$

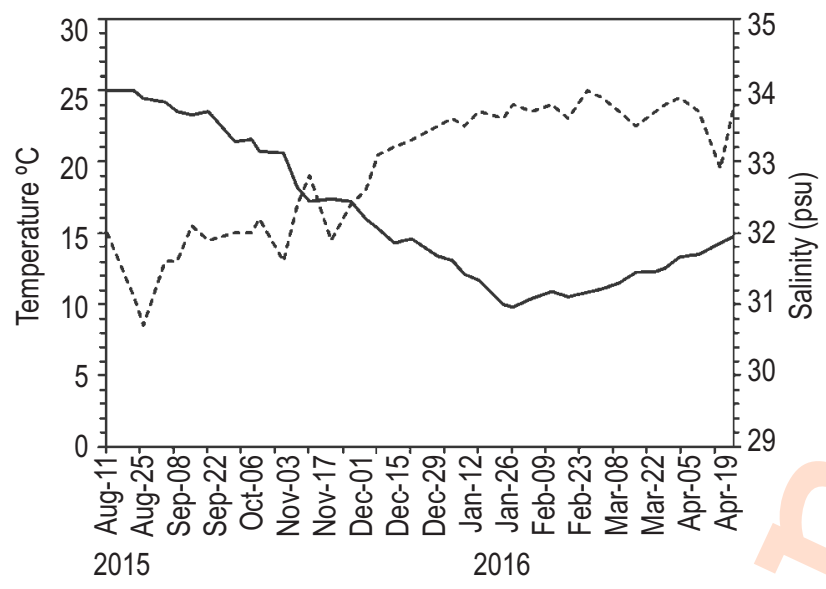

Fig. 2 : Egg production rates of Acartia steueri at five different temperatures. Values are mean \pm SE of each treatment. One-way ANOVA was performed between the treatments followed by TukeyKarmar multiple comparison test $(P<0.05)$. Letters $(a, a b, b c, c d$, and $d)$ represent statistical significance between each treatment.

size of copepods decreases with increasing temperature. The eggs of Acartia tonsa produced at $6^{\circ} \mathrm{C}$ was $85 \mu \mathrm{m}$ in diameter, but decreased to $80 \mu \mathrm{m}$ at $24^{\circ} \mathrm{C}$ (Hansen et al., 2010). The egg diameter of Acartia tonsa was $82.2 \mu \mathrm{m}$ at low temperature $\left(6.5^{\circ} \mathrm{C}\right)$ and $78.4 \mu \mathrm{m}$ at $17.5^{\circ} \mathrm{C}$ (Uye and Fleminger, 1976). The egg size of Sinodiaptomus (Rhinediaptomus) indicus also decreased with increasing temperature, but above optimum temperature $(\geq$ $30^{\circ} \mathrm{C}$ ), the egg size changed at the low temperature (Begum et al., 2012). In this study, the egg size of $A$. steueri showed similiar pattern with $A$. tonsa.

The egg size is affected by female body size. The body size is positively correlated with egg size (Dvoresky and Dvoretsky, 2014), but inversely with temperature (Kobari et al., 2003). In other words, the egg size increased with growing body

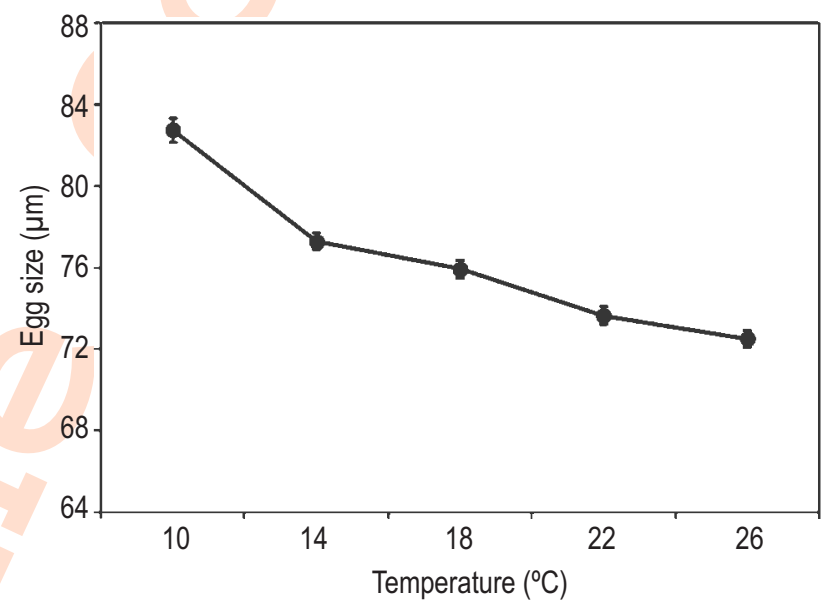

Fig. 3 : Egg size of Acartia steueriat five different temperatures.

size at low temperatures. The eggs produced from relatively small female is small because the space for mature oocyte is small (Niehoff, 2007). This research indicated that egg sizes are concerned with the number of egg and the arrangement of oocytes in the gonad.

Hatching success and embryonic development time : Hatching success rate of eggs were lowest at $10^{\circ} \mathrm{C}(2.1 \%)$ and increased sharply to $98 \%$ at $18^{\circ} \mathrm{C}$, followed by $94 \%$ and $77 \%$ at $22^{\circ} \mathrm{C}$ and $26^{\circ} \mathrm{C}$, respectively (Fig. 4). The relationship between embryonic development time and temperature of $A$. steueri was as follows

$$
D_{E}=40.4(T-5.9)^{-1.23} \quad\left(r^{2}=0.9737\right)
$$

The duration of embryonic development of $A$. steueri at five temperature regimes varied from 1.2 to 7.5 days. The embryonic development time was lowest at 7.5 days for $10^{\circ} \mathrm{C}$ and 1.2 days at $22^{\circ} \mathrm{C}$. The embryonic development at $26^{\circ} \mathrm{C}$, the highest temperature, was lower than $22^{\circ} \mathrm{C}$. 
Table 3: Analysis of variance (ANOVA test) of embryonic development of Acartia steueriat five different temperatures

\begin{tabular}{lllll}
\hline Source of variation & d.f & Sum of squares & Mean squares & F \\
\hline Temperature & 4 & 361956.9 & 90489.226 & 724.2 \\
\hline$P<0.05$
\end{tabular}

$P<0.05$

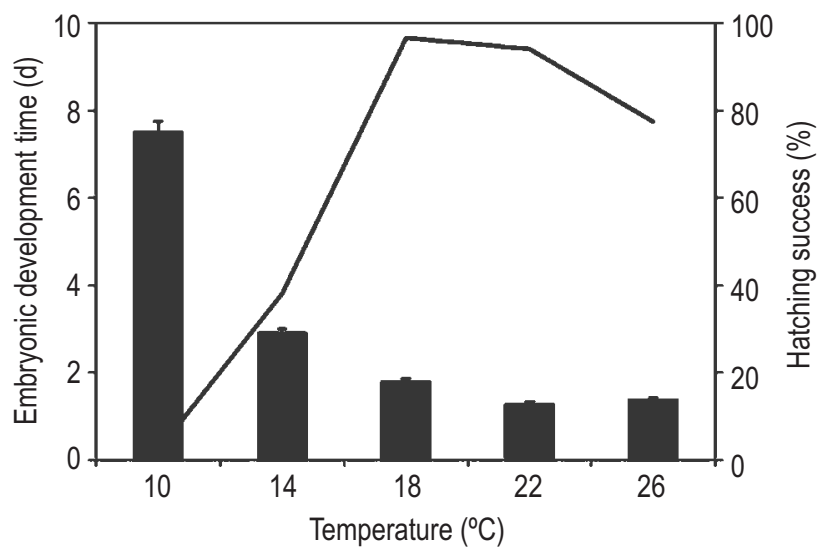

Fig. 4 : Embryonic development time (bar) and hatching success rates (line) of Acartia steueriat five different temperatures.

There was a significant relationship between duration and temperature of embryonic development (Table 3). Significant difference was observed at $10^{\circ} \mathrm{C}$ and $14^{\circ} \mathrm{C}$ than other temperature regimes $(p<0.05)$, while no significant difference was noted between $26^{\circ} \mathrm{C}$ and $22^{\circ} \mathrm{C}$ ( $p>0.05$, Tukey test).

Temperature is affected by embryonic development time (Yoshida et al., 2012). The embryonic development time of Thermocyclops neglectus increased when water temperature increased, and the embryonic development time was longer than the optimal temperature $\left(32.5^{\circ} \mathrm{C}\right)$ (Burgis, 1970). The egg development times of Acartia erythraea, $A$. pacifica and $A$. spinicauda were shortest at high temperature (Yoshida et al., 2012). Hatching time of Eurytemora affinis was 1.4 days at $5^{\circ} \mathrm{C}$, 1.6 days at $22^{\circ} \mathrm{C}$ and 0.5 day at $25^{\circ} \mathrm{C}$ (Andersen and Nielsen, 1997). The egg development times of Eurytemora affinis and Psudodiaptomus forbesi reduced with increasing temperature (Sullivan and Kimmerer, 2013). The egg development of cold water species (Cyclops vicinus and Diacyclops bicuspidatus) was faster than Mesocyclops leukarti and Thermocyclops crassus at 5 $-15^{\circ} \mathrm{C}$ (Maier, 1989). The result showed that temperature affect embryonic development times.

Hatching rate increased when temperature elevated, but decreased above optimum temperature. Hatching success rates were highest at $27^{\circ} \mathrm{C}, 22^{\circ} \mathrm{C}$ (or $27^{\circ} \mathrm{C}$ ) and $31^{\circ} \mathrm{C}$ for $A$. erythraea, A. pacifica and $A$. spinicauda, respectively and lowest at $10^{\circ} \mathrm{C}$ for all three species (Yoshida et al., 2012). Hatching rates of $A$. tonsa was highest at $23^{\circ} \mathrm{C}(92.2 \%)$, but there was no hatching $12^{\circ} \mathrm{C}$ (Holste and Peck, 2006). The hatching success of Calanus glacialis and C. finmarchicus from Disko Bay, Western Greenland was highest at low temperature $\left(0^{\circ} \mathrm{C}\right)$ and the egg development time of two species decreased with increasing temperature between $0^{\circ} \mathrm{C}$ and $10^{\circ} \mathrm{C}$ (Jung-Madsen and Nielsen, 2015). Because the optimum temperature of two species in Arctic was lower than experiment temperature regimes.

The hatching rate also showed pattern with the developmental time. Copepods have their own optimal temperature and salinity for the hatching success rate and developmental time. Thus, the hatching rate decreases and embryonic development time becomes longer when the temperature exceeds the optimal temperature.

Population variations of acartiidae : Total five Acartiid species appeared in the study area. A. steueri occurred continuously during the study period. The monthly mean densities ranged from 8.0 to 152.7 inds. $\mathrm{m}^{-3}$, which was highest in March, and lowest in August 2015 and January 2016, respectively. A. omorii was present continuously during the study period except October. Monthly mean densities ranged between $0-229.3$ inds. $\mathrm{m}^{-3}$, which was highest in February. A. sinjinesis appeared from August to January. A. pacifica occurred until December. The monthly mean density ranged between $0-108.5$ inds. $\mathrm{m}^{-3}, 0$ 17.0 ind. $\mathrm{m}^{-3}$, which was higher in October and September than other months. The monthly mean densities of $A$. erythraea were lowest from August to October, ranging between $1.8-5.5$ inds. $\mathrm{m}$ ${ }^{3}$ (Fig. 5).

Population variations in genus Acartia are influenced by environmental factors such as temperature, salinity and $\mathrm{Chl}$ a concentration (Soh, 2003). A. omorii are found between 6.19 $26.32^{\circ} \mathrm{C}$. A. pacifica and $A$. erythraea occur with a range between $18.07-27.28^{\circ} \mathrm{C}$ and $14.62-26.48^{\circ} \mathrm{C}$, respectively (Kang, 2011). The optimum water temperature for $A$. sinjinesis are $25.03-$ $27.5^{\circ} \mathrm{C}$ and $A$. steueri are found as $11.26-14.24^{\circ} \mathrm{C}$. A. omorii in the southern part of Korea was dominant in spring and early summer, and salinity (>33.0 psu) and $\mathrm{Chl}$ a concentration were high. However, due to increase in water temperature $\left(>20^{\circ} \mathrm{C}\right)$, the number of $A$. omorii decreased, and the number of $A$. erythraea and $A$. pacifica increased. In Okkirai Bay, Japan, $A$. omorii appears in winter and spring when water temperature is low, while A. steueri appears year-round except when the temperature is lowest (Yamada et al., 2012). In this study, A. steueri occurred continuously during the study period with peaks at lower temperature season. There was differences of $A$. steueri occurrence because different monthly water temperatures 




Fig. 5 : Population variations of Acartiid copepod in Dadaepo beach from August 2015 to April 2016.

between Okkirai Bay, Japan and the present study area. Okkirai Bay, Japan is located at higher latitude than the study area so that temperature of Okkirai Bay is lower than that of study areas. The highest temperature of Okkirai Bay, Japan all around the year is approximately $20^{\circ} \mathrm{C}$, while that of the study area was $25^{\circ} \mathrm{C}$. This difference in temperature change between two locations resulted different pattern of $A$. steueri occurrence. $A$. steueri at both areas occurred at similar water temperatures. Similar to previous studies, A. pacifica, A. erythraea and $A$. sinjiensis occupied the highest proportion of individuals when water temperature was high during the study period. As the temperature decreased, the proportion of individuals also decreased with decreasing water temperature. The optimum water temperature of $A$. omorii and $A$. steueri was lower than that of other species. Thus, population of acartiid species changes seasonally because the optimal habitat temperature differs from species to species.

\section{Acknowledgment}

This research was supported by "Long-term change of structure and function in marine ecosystems of Korea", funded by the Ministry of Oceans and Fisheries, Korea.

\section{References}

Ara, K.: Daily egg production rate of the planktonic calanoid copepod
Acartia lilljeborgi Giesbrecht in the Cananéia Lagoon estuarine system, So Paulo, Brazil. Hydrobiologia, 445, 205-215 (2001).

Andersen, C.M. and T.G. Nielsen: Hatching rate of the egg-carrying estuarine copepod Eurytemora affinis. Mar. Ecol. Prog. Ser., 160, 283-289 (1997).

Begum, B.D., G. Dharani and K. Altaff: Effect of temperature on the egg production and hatching success of Sinodiaptomus (Rhinediaptomus) indicus (Calanoida: Copepoda). Afr. J. Basic Appl. Sci., 4, 216-220 (2012).

Burgis, M.J.: The effect of temperature on the development time of eggs of Thermocyclops sp., a tropical cyclopoid copepod from Lake George, Uganda. Limnol. Oceanogr., 15, 742-747 (1970).

Castro-Longoria, E.: Egg production and hatching success of four Acartia species under different temperature and salinity regimes. J. Crustacean Biol., 23, 289-299 (2003).

Corkett, C.J. and I.A. McLaren: Relationships between development rate of eggs and older stages of copepods. J. Mar. Biol. Assoc. U. K., 50, 161-168 (1970).

Dvoretsky, V.G. and A.G. Dvoretsk: Egg production rates of two common copepods in the Barents Sea in summer. Polar Sci., 8, 298-305 (2014).

Guisande, C. and R. Harris: Effect of total organic content of eggs on hatching success and naupliar survival in the copepod Calanus helgolandicus. Limnol. Oceanogr., 40, 476-482 (1995).

Hansen, B.W., G. Drillet, R.M. Kristensen, T.F. Sørensen and M.T. Tøttrup: Production, hatching success and surface ornamentation of eggs of calanoid copepods during a winter at $57^{\circ} \mathrm{N}$. Mar. Biol., 157, 59-68 (2010). 
Hays, G.C., A.J. Richardson and C. Robinson: Climate change and marine plankton. Trends Ecol. Evol., 20, 337-344 (2005).

Holste, L. and M.A. Peck: The effects of temperature and salinity on egg production and hatching success of Baltic Acartia tonsa (Copepoda: Calanoida): Alaboratory investigation. Mar. Biol., 148, 1061-1070 (2006).

Jung-Madsen, S. and T.G. Nielsen: Early development of Calanus glacialis and C. finmarchicus. Limnol. Oceanogr., 60, 934-946 (2015).

Kang, H.K. and Y.J. Kang: Egg production of the copepod Acartia steueri in Ilkwang Bay, Southeastern Coast of Korea. Korean J. Fish. Aquat. Sci., 31, 288-295(1998).

Kang, J.H.: The occurrence of Acartia species and their environmental characteristics at three ports in Korea. Ocean Sci. J., 46, 219-237 (2011).

Kobari, T., K. Tadokoro, A. Shimoto and S. Hashimoto: Geographical variations in prosome length and body weight of Neocalanus copepods in the North Pacific. J. Oceanogr., 59, 3-10 (2003).

Koski, M. and H. Kuosa: The effect of temperature, food concentration and female size on the egg production of the planktonic copepod Acartia bifilosa. J. Plankton Res., 21, 1779-1790 (1999).

Landry, M.R.: The relationship between temperature and the development of life stages of the marine copepod Acartia clausi giesbrecht. Limnol. Oceanogr., 20, 854-857 (1975).

Liang, D. and S. Uye: Population variation and production of the planktonic copepods in a eutrophic inlet of the inland sea of Japan. II. Acartia omorii. Mar. Biol., 125, 109-117 (1996).

Lee, H.W., S. Ban, T. Ikeda and T. Matsuishi: Effect of temperature on development, growth and reproduction in the marine copepod Pseudocalanus newmani at satiating food condition. J. Plankton Res., 25, 261-271 (2003).

Maier, G.: The effect of temperature on the development times of eggs, naupliar and copepodite stages of five species of cyclopoid copepods. Hydrobiologia, 184, 79-88 (1989).

Mauchline, J.: The biology of Calanoid Copepods. Adv. Mar. Biol., 33, pp. 710 (1998).

Miller, C.B., J.K. Johnson and D.R. Heinle: Growth rules in the marine copepod genus Acartia. Limnol. Oceanogr., 22, 326-335 (1977).

$\mathrm{Na}$, J.Y., S.K. Han and K.D. Cho: A study on sea water and ocean current in the sea adjacent to Korea peninsula-expansion of coastal waters and its effect on temperature variations in the South Sea of Korea. Korean J. FishAquat. Sci., 23, 267-279 (1990).

Niehoff, B.: Life history strategies in zooplankton communities: The significance of female gonad morphology and maturation types for the reproductive biology of marine calanoid copepods. Prog. Oceanogr., 74, 1-47 (2007).

Santhanam, P., N. Jeyaraj and K. Jothiraj: Effect of temperature and algal food on egg production and hatching of copepod, Paracalanus parvus. J. Environ. Biol., 34, 243-246 (2013).

Soh, H.Y.: Spatio-temporal distribution of the genus Acartia (Copepoda: Calanoida) in the southwestern waters of Korea. Korean J. Environ. Biol., 21, 422-427 (2003).

Sullivan, L.J. and W.J. Kimmerer: Egg development times of Eurytemora affinis and Pseudodiaptomus forbesi (Copepoda, Calanoida) from the upper San Francisco Estuary with notes on methods. J. Plankton Res., 35, 1331-1338 (2013).

Üstün, F. and L. Bat: The egg production rate of Acartia (Acartiura) clause Giesbrecht, 1889 (Copepoda) in Sinop Peninsula (Southern Black Sea). Turk. J. Fish Aquat. Sci., 14, 605-613 (2014).

Uye, S.: Development of neritic copepods Acartia clausiand A. steueri. I.: Some environmental factors affecting egg development and the nature of resting eggs. Bull. Plankton Soc. Japan, 27, 1-9 (1980).

Uye, S.: Fecundity studies of neritic calanoid copepods Acartia clausi giesbrecht and $A$. steueri smirnov: A simple empirical model of daily egg production. J. Exp. Mar. Biol. Ecol., 50, 255-271 (1981).

Uye, S.: Population dynamics and production of Acartia clausi giesbrecht (Copepoda: Calanoida) in inlet waters. J. Exp. Mar. Biol. Ecol., 57, 55-83 (1982).

Uye, S. and A. Fleminger: Effects of various environmental factors on egg development of several species of Acartia in Southern California. Mar. Biol., 38, 253-262 (1976).

White, J.R. and M.R. Roman: Egg production by the calanoid copepod Acartia tonsa in mesohaline Cheaspeake Bay the importance of food resources and temperature. Mar. Ecol. Prog. Ser., 86, 239249 (1992)

Woodward, I.O. and R.W.G. Whit: Effects of temperature and food on the fecundity and egg development rates of Boeckella symmetrica Sars (Copepoda : Calanoida). Aust. J. Mar. Freshwater Res., 32, 997-1002 (1981).

Yamada, Y., A. Kobiyama and T. Ogata: Seasonal succession of four Acartia copepods (Copepoda, Calanoida) in Okkirai Bay, Sanriku, northern Japan. Plankton Benthos Res., 7, 188-194 (2012).

Yun, S.G. and S.G. Paik: Community structure of macrobenthos around Kadugdo, a south coast of Korea. Korean J. Fish. Aquat. Sci., 34, 493-501 (2001).

Yoo, K.I., H.K. Hue and W.C. Lee: Taxonomical revision on the genus Acartia (Copepoda: Calanoida) in the Korean waters. Korean J. Fish Aquat. Sci., 24, 255-265 (1991).

Yoshida, T., C.F. Liong, A.M. Majid, T. Toda and B.H.R. Othman: Temperature effects on the egg development time and hatching success of three Acartia species (Copepoda: Calanoida) from the Strait of Malacca. Zool. Stud., 51, 644-654 (2012).

Zamora-Terol, S. and E. Saiz: Effects of food concentration on egg production and feeding rates of the Cyclopoid copepod Oithona davisa. Limnol. Oceanogr., 58, 376-387 (2013). 